\title{
Effect of Andrographolide Co-Administration on Pharmacokinetics of Meloxicam in Rats
}

\author{
V.L. Gondaliya Vaishali ${ }^{1}$, J.H. Patel ${ }^{1 *}$, R.D. Varia ${ }^{1}$, S.K. Bhavsar ${ }^{1}$, \\ P.D. Vihol Priti ${ }^{2}$, F.D. Modi Falguni ${ }^{1}$ and T.H. Solanki Tamanna ${ }^{1}$ \\ ${ }^{1}$ Department of Pharmacology and Toxicology, ${ }^{2}$ Department of Veterinary Pathology, Veterinary \\ College, Navsari Agricultural University, Navsari, Gujarat, India \\ *Corresponding author
}

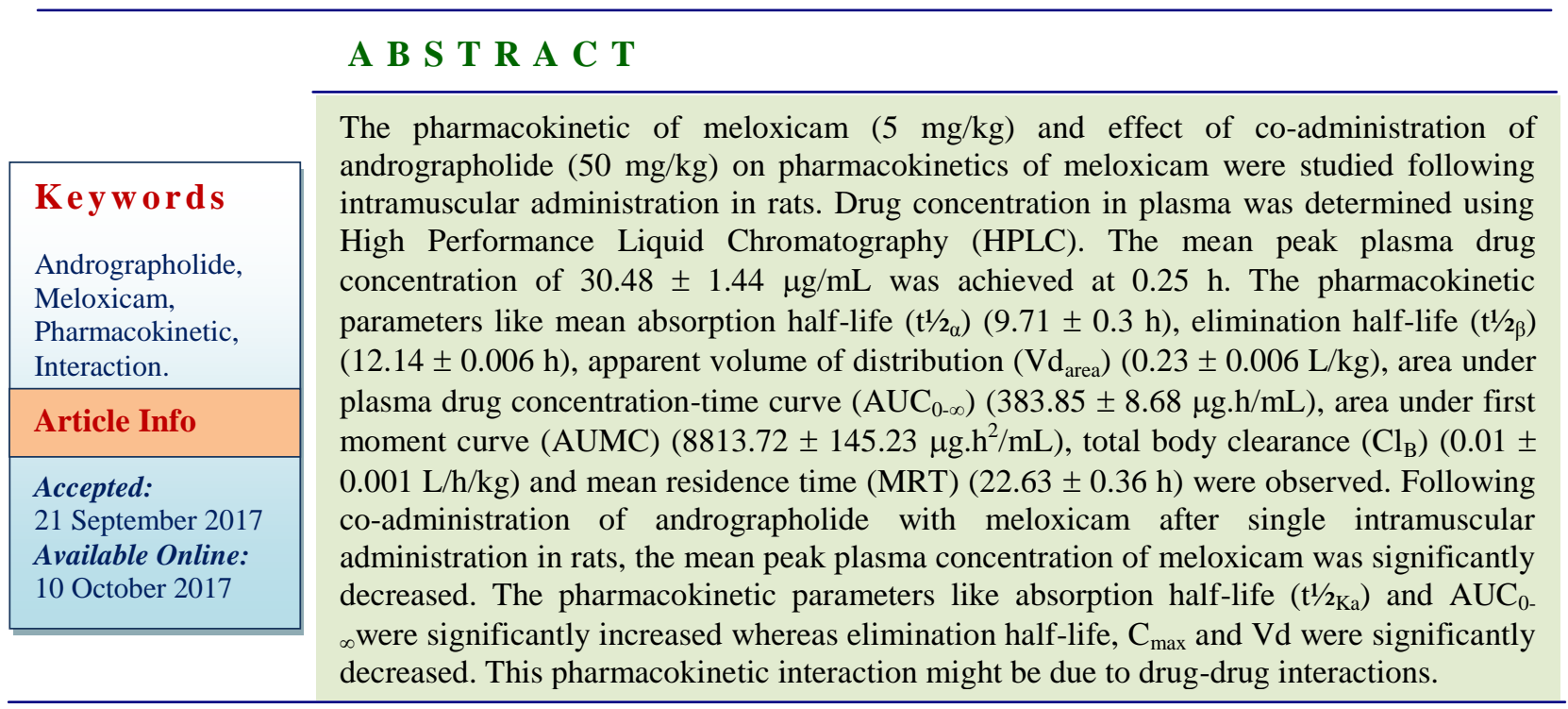

\section{Introduction}

Meloxicam is a non-steroidal antiinflammatory drug from the subgroup of enolic acid oxicams. Meloxicam is a novel NSAID that has effectively replaced the old pain killers particularly diclofenac sodium which has high toxicity. Meloxicam has a high intrinsic activity combined with a low ulcerogenic potential (i.e. a high therapeutic index) (Engelhardt et al., 1996).Meloxicam is considered as standard non-steroidal antiinflammatory drug which metabolized by the cytochrome P450 (CYP) subgroup of isoenzymes, possibly $\mathrm{CYP} 2 \mathrm{C} 9 / 2 \mathrm{C} 8$ and
CYP3A4 (Schmid et al., 1995; Chesné et al., 1998). Andrographolide (diterpene lactone) is main chemical constituent of plant Andrographis paniculata. It is widely used as home remedies against various aliments like throat infection, pneumonia, tonsillitis, dysentery, gastroenteritis and pyelonephritis (Deng et al., 1982). Moreover, it is reported that andrographolide modulate expression of several cytochromes $\mathrm{P} 450$ isoenzymes like CYP2C9, CYP3A4, CYP2C6/11, CYP1A1/2 and CYP3A1/2. (Chesné et al., 1998; Schmidet al., 1995; Pekthong et al., 2008; 
Pekthonget al., 2009) and therefore herb preparations containing andrographolide may result to herb-drug interactions in combination therapy.

So effect of using common medicine in combination with modern pharmaceuticals like meloxicam remains to be verified (Ernst, 1998; Patel et al., 2015; Ratndeep et al., 2009). Looking to this background this study was planned to evaluate effect of andrographolide co-administration on pharmacokinetics of meloxicam in rats.

\section{Materials and Methods}

\section{Experimental animals}

The experiment was conducted on male albino Wistar rats weighing between 250 to 350 grams. Rats were kept under constant observation for two weeks before the commencement of the experiment and subjected to clinical examination to exclude possibility of any diseases.

The animals were divided into groups and kept in cages. Standard ration and water was provided ad libitum. The experimental protocol was approved by Institutional Animal Ethics Committee.

\section{Drug and chemicals}

Pure Andrographolide (98\%), meloxicam sodium salt hydrate (>98\%) and lambda carrageenan was obtained from SigmaAldrich St. Louis, USA. Methanol, acetonitrile and ortho-phosphoric acid (HPLC grade) were purchased from Merck Specialties Private Limited, Mumbai.

\section{Pharmacokinetic study and data analysis}

Animals $(\mathrm{n}=48)$ were divided into 12 groups. Each group comprise of four animals.
Multiple numbers of rats were used for serial collection of blood at alternating time points. A single intramuscular injection of meloxicam $(5 \mathrm{mg} / \mathrm{kg})$ was administered in the left gluteal muscle and for interaction pharmacokinetic meloxicam $(5 \mathrm{mg} / \mathrm{kg})$ and andrographolide $\quad(50 \quad \mathrm{mg} / \mathrm{kg}) \quad$ were administered by intramuscular route left and right gluteal muscle respectively. Blood samples were collected in $\mathrm{K}_{3}$ EDTA vials, at different time interval i.e. $0.75,1,2,4,6,8$, $12,24,36,48$ and60 hours from retro orbital plexus. Blood samples were centrifuged at $3000 \mathrm{rpm}$ for 10 minutes at $4^{\circ} \mathrm{C}$ and plasma was transferred to cryo-vials and, stored at $20^{\circ} \mathrm{C}$. Samples were analyzed within $48 \mathrm{~h}$ to quantify meloxicam concentration using High Performance Liquid Chromatography.

Meloxicam concentration in plasma samples was determined by reverse-phase High Performance Liquid Chromatography (HPLC) after extraction, using reported assays (Eniko et al., 2014; Gondaliya et al., 2015; Patel et al., 2016) with minor modifications. The high performance liquid chromatography apparatus of Shimadzu comprising binary gradient delivery pump (model LC - 20AP) and UV detector (model CBM-20A) was used for assay. Chromatographic separation was performed by using reverse phase C18 column (ODS; $250 \times 4.6 \mathrm{~mm} \mathrm{ID)} \mathrm{at} \mathrm{room}$ temperature. The HPLC data integration was performed using software Clarity. Plasma $(100 \mu \mathrm{L})$ was deproteinized by addition of acetonitrile $(100 \mu \mathrm{L})$ and vortexed for one minute. This was followed by centrifugation at $8000 \mathrm{rpm}$ for 10 minutes. The clean supernatant was collected and an appropriate aliquot of $20 \mu \mathrm{l}$ of supernatant was injected into the loop of HPLC system through auto injector. The mobile phase consisted of a mixture of methanol and water $(80: 20 \mathrm{v} / \mathrm{v})$ adjusted to $\mathrm{pH} 3.5$ with ortho-phosphoric acid. Mobile phase was filtered by $0.2 \mu$ size filter (Axiva N66) and degassed by ultra- 
sonication. It was pumped into column by isocratic flow rate of $1.0 \mathrm{~mL} / \mathrm{min}$ at ambient temperature. The effluent was monitored at $355 \mathrm{~nm}$ wavelength. Various pharmacokinetic parameters were calculated from plasma concentration of meloxicam using software PK solution (Version 2.0).

\section{Standardization and partial validation of assay}

Initial stock solution was prepared by dissolving $2 \mathrm{mg}$ pure meloxicam drug in 2 $\mathrm{mL}$ free plasma. The assay was sensitive, reproducible and linearity was observed from 0.04 to $200 \mu \mathrm{g} / \mathrm{mL}$. The mean correlation coefficient $\left(\mathrm{R}^{2}\right)$ was 0.99 . The limits of detection and limits of quantification were determined to be 0.09 and $0.19 \mu \mathrm{g} / \mathrm{mL}$, respectively. Precision and accuracy of the assay were assessed using samples at concentration 50, 25, 1.56, 0.39 and 0.09 $\mu \mathrm{g} / \mathrm{mL}$. At all concentration studied, the C.V. was less than $8.7 \%$.

\section{Statistical analysis}

Meloxicam plasma concentration and pharmacokinetic parameters of different treatment groups were compared by using student t-test using Microsoft excel 2007.

\section{Results and Discussion}

The plasma concentration of meloxicam at different time interval following administration of meloxicam alone and concurrent administration of andrographolide is presented as Semilogarithmic plot in Figure 1 .

Following intramuscular administration of meloxicam alone, the mean peak plasma drug concentration of $30.48 \pm 1.44 \mu \mathrm{g} / \mathrm{mL}$ was achieved at $0.25 \mathrm{~h}$ which declined to $14.97 \pm$ $0.43 \mu \mathrm{g} / \mathrm{mL}$ at $4 \mathrm{~h}$. Thereafter, drug concentration decline gradually and detected upto $48 \mathrm{~h}(2.62 \pm 0.11 \mu \mathrm{g} / \mathrm{mL})$ and beyond then the drug was not detected in plasma. Following co-administration of andrographolide, meloxicam peak plasma concentration was significantly decreased to $23.67 \pm 0.48 \mu \mathrm{g} / \mathrm{mL}$ from $30.48 \pm 1.44 \mu \mathrm{g} / \mathrm{mL}$. Comparison of pharmacokinetics parameters of meloxicam and co-administration of andrographolide with meloxicam following intramuscular administration are presented in Table 1.

Elimination half-life $\left(\mathrm{t}_{1 / 2 \beta}: 12.14 \pm 0.006 \mathrm{~h}\right)$ of meloxicam $(5 \mathrm{mg} / \mathrm{kg})$ following intramuscular administration in rats was in agreement to elimination half-life $\left(\mathrm{t}_{1 / 2 \beta}: 13.4 \mathrm{~h}\right)$ reported following intravenous administration in albino rats (Busch et al., (1998). However, shorter elimination half-life were reported in mice following intravenous $(6.41 \mathrm{~h})$ and oral (4.76 h) administration (Busch et al., 1998), in rabbits following oral administration (8.16 $\pm 2.19 \mathrm{~h}$ and $8.39 \pm 1.17 \mathrm{~h})$ of meloxicam $(0.3$ and $1.5 \mathrm{mg} / \mathrm{kg}$ ) respectively (Turner et al., 2006) and in flamingo (1.93 $\pm 0.32 \mathrm{~h}$ and 6.05 $\pm 3.53 \mathrm{~h}$ ) following intramuscular and oral administration $(0.5 \mathrm{mg} / \mathrm{kg})$, respectively (Zordan et al., 2016). Mean apparent volume of distribution $\left(\mathrm{Vd}_{\text {area }}: 0.23 \pm 0.006 \mathrm{~L} / \mathrm{kg}\right)$ of meloxicam following intramuscular administration in rats was found lower in comparison to reported in rabbits $(1.46 \pm 0.48$ $\mathrm{L} / \mathrm{kg}$ and $4.14 \pm 1.03 \mathrm{~L} / \mathrm{kg}$ ) following single oral administration (0.3 and $1.5 \mathrm{mg} / \mathrm{kg})$, respectively (Turner et al., 2006).This finding was supported by higher value of AUC(383.85 $\pm 8.68 \mu \mathrm{g} . \mathrm{h} / \mathrm{mL})$ of meloxicam in rats,in comparison to findings reported following intravenous administration in male (60.7 $\mu \mathrm{g} . \mathrm{h} / \mathrm{mL})$; oral administration in female and male mice (89.5 $\mu \mathrm{g} . \mathrm{h} / \mathrm{mL}$ and 60.7 $\mu \mathrm{g} . \mathrm{h} / \mathrm{mL})$ respectively; intravenous and oral administration in albino rats (70.9 and 83.3 $\mu \mathrm{g} . \mathrm{h} / \mathrm{mL}$ ) (Busch et al., 1998); oral administration in rabbits (5.20 \pm 1.29 $\mu \mathrm{g} . \mathrm{h} / \mathrm{mL}$ ) (Turner et al., 2006); intramuscular 
and oral administration in flamingo $(17.78 \pm$ $2.79 \mu \mathrm{g} . \mathrm{h} / \mathrm{mL}$ and $22.16 \pm 7.17 \mu \mathrm{g} . \mathrm{h} / \mathrm{mL})$ respectively (Zordan et al., 2016) and oral, intravenous and subcutaneous administration in dogs $(22.9,21.5$ and $24.1 \mu \mathrm{g} . \mathrm{h} / \mathrm{mL})$ respectively (Busch et al., 1998).

Table.1 Comparison of pharmacokinetics parameters of meloxicam $(5 \mathrm{mg} / \mathrm{kg})$ alone and coadministration of andrographolide $(50 \mathrm{mg} / \mathrm{kg})$ with meloxicam $(5 \mathrm{mg} / \mathrm{kg})$ following intramuscular administration in rats.

\begin{tabular}{|c|c|c|c|}
\hline $\begin{array}{c}\text { Pharmacokinetic } \\
\text { parameters }\end{array}$ & Unit & Meloxicam & $\begin{array}{c}\text { Co-administration of } \\
\text { Andrographolide and Meloxicam }\end{array}$ \\
\hline $\mathrm{K}_{\mathrm{a}}$ & $\mathrm{h}^{-1}$ & $0.07 \pm 0.002$ & $0.06 \pm 0.001^{*}$ \\
\hline$\beta$ & $\mathrm{h}^{-1}$ & $0.057 \pm 0$ & $0.058 \pm 0.00^{*}$ \\
\hline $\mathrm{t}^{1 / 2} \mathrm{Ka}$ & $\mathrm{H}$ & $9.71 \pm 0.3$ & $11.8 \pm 0.12^{*}$ \\
\hline $\mathrm{t}^{1} / 2 \beta$ & $\mathrm{H}$ & $12.14 \pm 0.006$ & $11.8 \pm 0.38^{*}$ \\
\hline $\mathrm{C}_{\max }$ & $\mu \mathrm{g} / \mathrm{mL}$ & $30.62 \pm 1.45$ & $23.7 \pm 0.48^{*}$ \\
\hline $\mathrm{T}_{\max }$ & $\mathrm{H}$ & $0.25 \pm 0$ & $0.25 \pm 0.00$ \\
\hline $\mathrm{AUC}(0-\infty)$ & $\mu \mathrm{g} \cdot \mathrm{h} / \mathrm{mL}$ & $383.85 \pm 8.68$ & $435 \pm 6.58^{* *}$ \\
\hline $\mathrm{AUMC}$ & $\mu \mathrm{g} \cdot \mathrm{h}^{2} / \mathrm{mL}$ & $8813.72 \pm 145.23$ & $9451.8 \pm 176.19^{*}$ \\
\hline $\mathrm{Vd}_{(\mathrm{area})}$ & $\mathrm{L} / \mathrm{kg}$ & $0.23 \pm 0.006$ & $0.19 \pm 0.003^{* *}$ \\
\hline $\mathrm{Cl}_{(\mathrm{B})}$ & $\mathrm{L} / \mathrm{h} / \mathrm{kg}$ & $0.01 \pm 0.001$ & $0.01 \pm 0.00$ \\
\hline $\mathrm{MRT}$ & $\mathrm{h}$ & $22.63 \pm 0.36$ & $21.7 \pm 0.20$ \\
\hline
\end{tabular}

$*$ Significant at $\mathrm{p}<0.05, * *$ Highly significant at $\mathrm{p}<0.01$

Fig.1 Semilogarithmic plot of comparison of meloxicam $(5 \mathrm{mg} / \mathrm{kg})$ and co-administration of andrographolide $(50 \mathrm{mg} / \mathrm{kg})$ with meloxicam $(5 \mathrm{mg} / \mathrm{kg})$ following intramuscular administration in rats. Each points represents mean \pm S.E

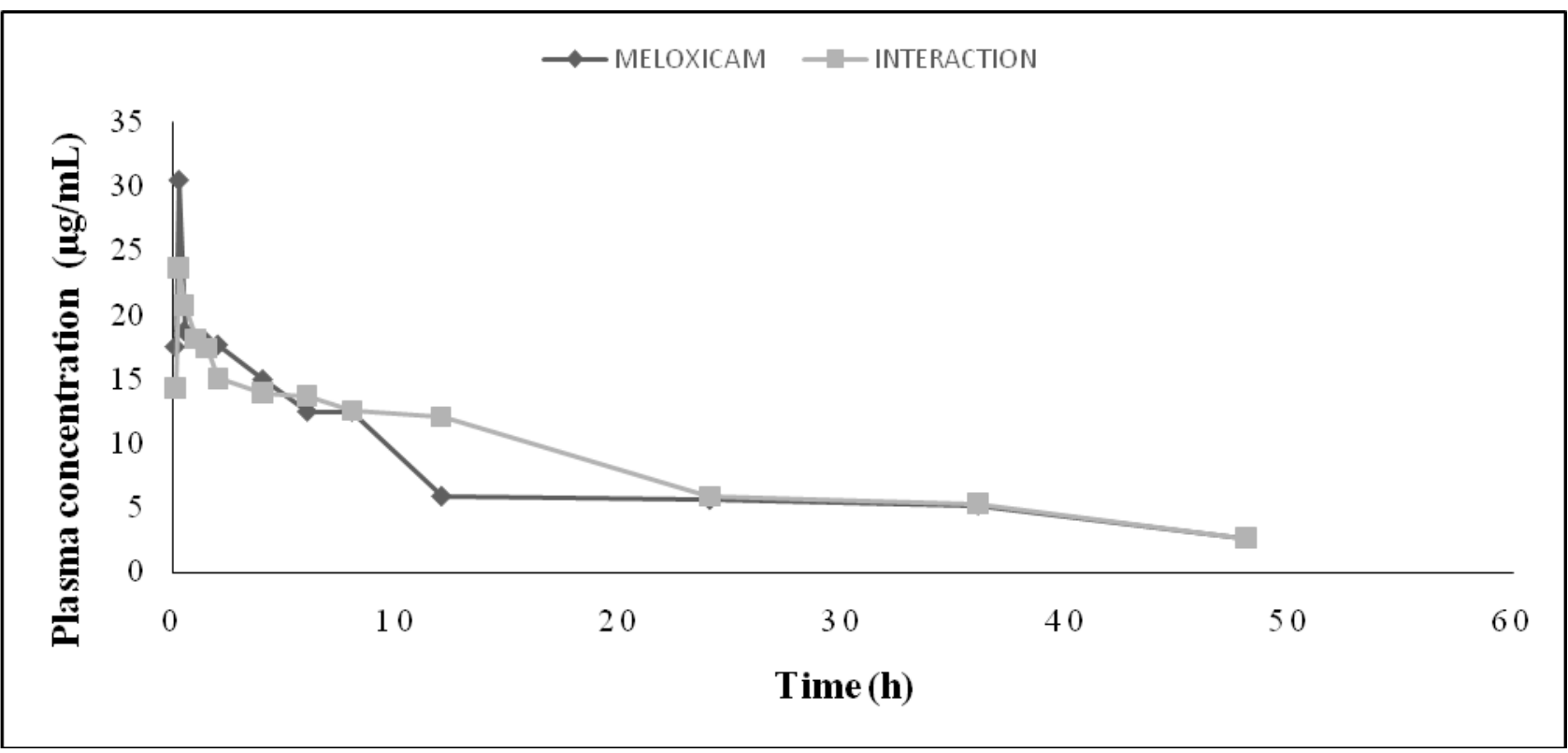


In the present study the total body clearance $(0.013 \pm 0.001 \mathrm{~L} / \mathrm{h} / \mathrm{kg})$ of meloxicam following intramuscular administration (50 $\mathrm{mg} / \mathrm{kg}$ ) in rats was found in accordance with values of total body clearance reported following intravenous administration in male albino rats $(0.015 \mathrm{~L} / \mathrm{h} / \mathrm{kg})$; oral administration male and female albino rats $(0.023 \mathrm{~L} / \mathrm{h} / \mathrm{kg}$ and $0.010 \mathrm{~L} / \mathrm{h} / \mathrm{kg}$ ) respectively, intravenous administration to dogs $\left(0.010 \mathrm{~L} / \mathrm{h}^{\prime} \mathrm{kg}\right)$ (Busch et al., 1998). However, higher value of total body clearance was reported in rabbits $(0.12 \pm$ $0.01 \mathrm{~L} / \mathrm{h} / \mathrm{kg}$ and $0.33 \pm 0.06 \mathrm{~L} / \mathrm{h} / \mathrm{kg}$ ) following single oral administration ( 0.3 and $1.5 \mathrm{mg} / \mathrm{kg}$ ), respectively (Turner et al., 2006). Mean residence time (MRT : $22.63 \pm 0.36 \mathrm{~h}$ ) was found in accordance with values reported following oral administration in male $(31.8 \mathrm{~h})$ and female $(53.4 \mathrm{~h})$ albino rats; intravenous $(18 \mathrm{~h})$ administration in male albino rats and oral $(40 \mathrm{~h})$, intravenous $(34.8 \mathrm{~h})$ and subcutaneous $(35 \mathrm{~h})$ administration in dogs (Busch et al., 1998). However, lower MRT values following intravenous $(3.02 \mathrm{~h})$ and oral (3.89 h) administration in mice (Busch et al., 1998) were also reported. Low volume of distribution $\left(\mathrm{Vd}_{\text {area }}\right)$ of meloxicam following intramuscular administration in present study may be due to strong binding of drug to serum albumin (>99\%) in rats (Busch et al., 1998). It is evident that meloxicam gets eliminated slowly following intramuscular administration in rats as elimination half-life and mean residence time values indicates that meloxicam remain longer period of time compare to the intravenous and oral administration in rats.

Following co-administration of andrographolide with meloxicam after single intramuscular administration in rats, absorption half-life $\left(\mathrm{t}^{1 / 2} \mathbf{2}_{\mathrm{Ka}}\right)$ and $\mathrm{AUC}_{0-\infty}$ were significantly increased from $9.71 \pm 0.3 \mathrm{~h}$ to $11.8 \pm 0.12 \mathrm{~h}$ and $383.85 \pm 8.68$ to $435 \pm 6.58$ $\mu \mathrm{g} \cdot \mathrm{h} / \mathrm{ml}$, respectively and elimination halflife, $C_{\max }$ and $\mathrm{Vd}_{\text {area }}$ were significantly decreased from $12.14 \pm 0.006$ to $11.8 \pm 0.38$ h, $30.62 \pm 1.45$ to $23.7 \pm 0.48 \mu \mathrm{g} / \mathrm{ml}$ and 0.23 \pm 0.006 to $0.19 \pm 0.003 \mathrm{~L} / \mathrm{kg}$, respectively. In accordance to present study, alteration in pharmacokinetic parameter was observed like clearance of theophylline was significantly increased in Andrographis paniculata extract $(1 \mathrm{~g} / \mathrm{kg})$ treated group rats, elimination halflife of theophylline was significantly decreased in andrographolide (154 mg/kg) treated group rats and $\mathrm{AUC}_{0-\infty}$ of theophylline were significantly decreased in Andrographis paniculata extract (2 $\mathrm{g} / \mathrm{kg})$ and andrographolide $(154 \mathrm{~g} / \mathrm{kg})$ treated group rats. While elimination half-life and mean residence time of theophylline were shortened about 14 and $17 \%$ in the andrographolide (77 $\mathrm{mg} / \mathrm{kg}$ ) pretreated group rats (Chao et al., 2010). Similarly Andrographis paniculata extract and andrographolide reduced the $\mathrm{AUC}_{0-12 \mathrm{~h}}$ of tolbutamide by $37 \%$ and $18 \%$, respectively (Chen et al., 2013). However, no significant effect of andrographolide on pharmacokinetics of warfarin (Hovhannisyan et al., 2006) and midazolam (Wongnawa et al., 2012) was observed. Alteration in pharmacokinetic of meloxicam may be due to metabolism of meloxicam caused by major extent through CYP2C9 and, to a much lesser extent, CYP3A4 (Schmid et al., 1995; Chesné et $a l ., 1998)$ and andrographolide was also found to modulate expression of CYP2C9 and CYP3A4 microsomal enzyme (Pekthong et al., 2008; Pekthong et al., 2009).

\section{Acknowledgement}

The facility and infrastructure provided by Dean, College of Veterinary science and A. H., Navsari to conduct this study is duly acknowledged.

\section{References}

Busch, U., Schmid, J., Heinzel, G., Schmaus, H., Baierl, J., Huber, C. and Roth, W. 
1998. Pharmacokinetics of meloxicam in animals and the relevance to humans. Drug metabolism and disposition, 26(6): 576-584.

Chao, W. W., Kuo, Y. H. and Lin, B. F. 2010. Anti-inflammatory activity of new compounds from Andrographis paniculata by NF- $\mathrm{KB}$ transactivation inhibition. Journal of agricultural and food chemistry, 58(4):2505-2512.

Chen, H. W., Huang, C. S., Liu, P. F., Li, C. C., Chen, C. T., Liu, C. T. and Lii, C. K. 2013. Andrographis paniculata extract and andrographolide modulate the hepatic drug metabolism system and plasma tolbutamide concentrations in rats. Evidence-Based Complementary and Alternative Medicine, 2013.

Chesné, C., Guyomard C, Guillouzo A, Schmid J, Ludwig E, Sauter T. 1998. Metabolism of Meloxicam in human liver involves cytochromes P4502C9 and 3A4. Xenobiotica.28 (1):1-13.

Deng, W. L., Nie, R. J. and Liu, J. Y. 1982. Comparison of pharmacological effect of four andrographolides. Yaоxиe Tongbao, 17: 195-198.

Engelhardt, G., Bögel, R., Schnitzler, C. H. R. and Utzmann, R. 1996b. Meloxican: Influence on arachidonic acid metabolism: Part II. In vivo findings. Biochemical pharmacology, 51(1): 2938 .

Eniko, C., Ibolya, F. and Daniela-Lucia, M. 2014. Development of a HPLC-UV method for determination of meloxicam in human plasma and pharmaceutical dosage forms. Acta Medica Marisiensis, 60(4): 142-145.

Ernst, E., 1998. Harmless herbs? A review of the recent literature. The American journal of medicine, 104(2):170-178.

Gondaliya, S. R., Bhavsar S. K., Singh R. D., Patel J. H. and Thaker A. M. 2015. Pharmacokinetics and intramuscular bioavailability of Ketoprofen in patanwadi sheep. Journal of Veterinary Pharmacology and Toxicology, 14(2): 53-55.

Hovhannisyan, A. S., Abrahamyan, H., Gabrielyan, E. S. and Panossian, A. G. 2006. The effect of Kan Jang extract on the pharmacokinetics and pharmacodynamics of warfarin in rats. Phytomedicine, 13(5): 318-323.

Patel, J. H., Vihol Priti D., Patel U. D.,Varia R. D., Bhavsar S. K. and Thaker A. M. 2015. Effect of ketoprofen coadministration and febrile state on pharmacokinetic of Levofloxacin in goats. Journal of Veterinary Pharmacology and Toxicology. 14(1): 22-25

Patel, R.L., Bhavsar S.K., Tiwari Shireen, Patel J.H., Varia R.D. and Modi Falguni 2016. Effect of meloxicam coadministration on pharmacokinetic of cefquinome in cow calves. Journal of Veterinary Pharmacology \& Toxicology. 15(2): 84-86.

Pekthong, D., Blanchard N, Abadie C, Bonet A, Heyd B, Mantion G, Berthelot A, Richert L, Martin H. 2009. Effects of Andrographis paniculata extract and Andrographolide on hepatic cytochrome P450 mRNA expression and monooxygenase activities after in vivo administration to rats and in vitro in rat and human hepatocyte cultures. Chemico-Biological Interactions. 179(2-3):247-55.

Pekthong, D., Martin, H., Abadie, C., Bonet, A., Heyd, B., Mantion, G. and Richert, L. 2008. Differential inhibition of rat and human hepatic cytochrome P450 by Andrographis paniculata extract and andrographolide. Journal of ethnopharmacology, 115(3): 432-440.

Ratndeep Singh, Sarita Devi, Patel J. H., Patel U. D., Bhavsar S. K. and Thaker A.M. 2009. Indian herbal bioenhancer: a review. Pharmacognosy review. 
3(1):80-82.

Schmid, J., Busch, U., Heinzel, G., Bozler, G., Kaschke, S. and Kummer, M. 1995. Pharmacokinetics and metabolic pattern after intravenous infusion and oral administration to healthy subjects. Drug metabolism and Disposition, 23(11), 1206-1213.

Turner, P. V., Chen, C. H. and Taylor, M. W. 2006. Pharmacokinetics of meloxicam in rabbits after single and repeat oral dosing. Comparative medicine, 56(1): 63-67.

Wongnawa, M., Soontaro, P., Riditid, W., Wongpoowarak, P. and Ruengkittisakul,
S. 2012. The effects of Andrographis paniculata (Burm. f.) Nees on the pharmacokinetics and pharmacodynamics of midazolam in healthy volunteers. Songklanakarin Journal of Science and Technology, 34(5): 533-9.

Zordan, M. A., Papich, M. G., Pich, A. A., Unger, K. M. and Sánchez, C. R. 2016. Population pharmacokinetics of a single dose of meloxicam after oral and intramuscular administration to captive lesser flamingos (Phoeniconaias minor). American Journal of Veterinary Research, 77(12): 1311-1317.

\section{How to cite this article:}

Gondaliya Vaishali, V.L., J.H. Patel, R.D. Varia, S.K. Bhavsar, P.D. Vihol Priti, F.D. Modi Falguni and Solanki Tamanna, T.H. 2017. Effect of Andrographolide Co-Administration on Pharmacokinetics of Meloxicam in Rats. Int.J.Curr.Microbiol.App.Sci. 6(10): 2147-2153. doi: https://doi.org/10.20546/ijcmas.2017.610.254 